authors because the information is presented well. It sounds good, and thus is accepted without empirical evidence of efficacy. When we learn how to make our effective principles and technology sound good, we will begin to make bigger large-scale differences in quality of life.

By continuing to read the research literature of our field, we will always have the edge on knowing what works best to make a difference. However, the challenge of effective dissemination must be addressed if we want to translate thinking big into acting big.

Psychology Department

Virginia Polytechnic Institute and State University

Blacksburg, Virginia 24061-0436

Mary Louise Wright (Business Manager, 1968- ）

\title{
HOW TIME FLIES!
}

Way back in 1967 , when $J A B A$ was so new that it did not yet have a name, there was much excitement in Lawrence, Kansas. Mont Wolf s election as the new journal's first editor made everyone at KU terribly proud, especially those close to the newly reorganized Department of Human Development and Family Life.

Margaret Risley was hired by Mont to help him put efficient editorial procedures in place. She also searched for someone who could design the cover, and eventually found a printer in Kansas City who was willing to comply with her request to be shown at least 24 different color combinations for her tentative cover design.

Mont also needed a business manager. When he asked me if I would be interested in the job, he reported that his wife had made the suggestion because "Mary Lou is organized." Probably true. Sandra Wolf and I ran the Lawrence branch of the Kansas City Planned Parenthood. My second child had just been born, and Mont's description of the job seemed ideal: earn some money and still be at home with the children.

$J A B A$ started out on a desk in my study. Mont had said the founding powers hoped the journal, whose first issue was to appear during the Spring of 1968 , would have 1,500 subscribers by the end of that year. But subscriptions poured in so rapidly that we had reached almost 4,300 by then, so I moved $J A B A$ to the "weaving room" upstairs. I soon sold the loom, concluding correctly that I'd never again find time for such big projects. By the end of Mont's 3-year term, we had almost 5,500 subscribers.

The creation of $J A B A$ was relatively easy, for it was started by the Society for the Experimental Analysis of Behavior (SEAB), which was already publishing the Journal of the Experimental Anal$y$ sis of Bebavior (JEAB). Ten years earlier, the founders of $J E A B$ (and SEAB) had scrounged to find enough money to start the journal. Now there was enough money in the bank to afford sending out 19,000 brochures to prospective $J A B A$ subscribers and to give away sample copies galore. At the Eastern Psychological Association meeting in Washington, we gave away about 1,000 copies of the first issue, with the aid of the friendly equipment manufacturers, who were constant advertisers in $J E A B$ and had also taken space in $J A B A$. They allowed us to display stacks of the first issue in their exhibition hall booths.

Most important to me was the expertise and 
guidance I received from the business manager of $J E A B$, Kay Dinsmoor. She would send me very detailed information on $J E A B$ 's procedures, along with suggestions on billing, possible advertising copy, and a multitude of other problems. Very quickly Kay and I became fast friends. Some years ago I remember Don Hake saying that he manufactured reasons to write Kay because he loved to get letters from her. Me too! Early on in our phone visits, Kay and I discovered that we were the only two people we knew who alphabetized their spice shelves. We still try to one-up one another, testing each other with zip codes. Ask either of us a zip code, especially for a university town, and you'll probably be five-digited right back. Once, when I was in Bloomington, visiting Kay with a friend, the friend didn't find our conversation too boring until we started discussing Canadian zip codes.

As the assistant secretary-treasurer of SEAB, Kay is the one the Internal Revenue Service visits every few years to verify SEAB's tax-exempt status. She spreads the records out on her dining room table, and depending upon how she feels toward the IRS that year, may or may not offer coffee. One auditor questioned why no office space expenses were listed: no rent, no utilities. Kay explained that these offices existed in the business managers' (and managing editor's) homes. Even though the mailing address for $J A B A$ is the Department of Human Development at KU, my "office" there is a mailbox that measures about 4 by 6 by 10 inches. The mail is then delivered to my home, where the work is really done. Besides several upstairs rooms now devoted to $J A B A$, two thirds of my two-car garage is filled with back volumes. If I've recently received a shipment from the printer, I can't get the car into the garage at all. What other job can boast having, as an occupational hazard, a group of recluse spiders that spend their summer perusing the back volumes of a scientific journal?

When George Ackley came to Lawrence with Jon Bailey, then $J A B A$ 's editor, to visit Allen Press, where the journal is printed, he was somewhat taken aback by my rather unofficial-looking office. He asked if it was usually this messy, and I had to admit that I'd actually cleaned it up for his visit.
But Jon knew how it usually looked; when he was a graduate student at $\mathrm{KU}$, he sometimes baby-sat my two kids. But it's an organized mess, and I can easily find what I want when I want it.

For both Kay and me, journal operations sometimes took over both house and life. Even if you're "home sick," you're still not far from the telephone. Some years ago, the phone rang at the Dinsmoors' about 8 a.m. and Jim answered. It was a business call for Kay, and the caller from the New York advertising agency was taken aback when Jim said he'd check, but thought that Kay was still in bed.

Having a job at home, with flexible hours, also has meant that I was at home when the kids wandered in from school and that I could go to all their activities. I could also participate in activities that interested me: docenting at the KU Art Museum for about 10 years and serving on the Lawrence Board of Education for three terms (12 years), as president twice. Now that my kids are out of college, I have gone into partnership with a college friend to operate a bookstore in downtown Lawrence, one specializing in mysteries.

Both $J E A B$ and $J A B A$ are indebted to Vic Laties for his continuing interest and the time he contributes to the journals. Editors of the journals$J A B A$ editors at least - are usually so worn out that they aren't very active after they step down. Vic is there year after year, keeping an eye on expenses, trends, and other publications.

Each editor has brought both their special talents and their verve to the journal, and that is what keeps $J A B A$ exciting. (I have especially vivid memories of Brian Iwata at an ABA convention, selling $J A B A$ tee shirts.) I am very thankful to each and every one of them for the many, many hours they have devoted to producing the journal. I know it's always a relief for them to get back to research, colleagues, families, and friends.

Probably the unsung heroes of both journals are the managing editors. $J A B A$ initially used the late Garth Hopkins, who already was working with $J E A B$, and he assisted in getting the new journal off to a solid start. For many years, Sherrill Bushell charmed authors with her editing skills. When Sherrill decided to pursue other interests, we found 
Kathy Hill, who now manages both journals. We hope she will stay with them forever. Besides having a law degree, she has a phenomenal memory for items that appeared years ago. So, authors, CHECK your references!

Some years ago, Vic introduced me to someone at a meeting who frowned and said: "Gee, I thought you were a dunning agency." Maybe so; or perhaps
I'm just a myth hiding behind a typewriter somewhere in Lawrence, Kansas.

\author{
Department of Human Development \\ and Family Life \\ University of Kansas \\ Lawrence, Kansas 66045
}

